\title{
ANALISIS PROKSIMAT KARBON KULIT KEMIRI (ALEURITES MOLUCCANA) DENGAN VARIASI SUHU KARBONISASI
}

\author{
SARIFAH MUDAIM ${ }^{1 *}$, SAHRUL HIDAYAT $^{2}$, RISDIANA $^{2}$ \\ ${ }^{1}$ Magister Program, Department Fisika, Fakultas Matematika dan Ilmu Alam \\ Universitas Padjadjaran, Jl. Raya Bandung-Sumedang km 21 Jatinangor, Sumedang, \\ Jawa Barat, Indonesia 45363
}

${ }^{2}$ Department Fisika, Fakultas Matematika dan Ilmu Alam Universitas Padjadjaran Jl. Raya Bandung-Sumedang km 21 Jatinangor, Sumedang, Jawa Barat, Indonesia 45363

*email : sarifahmudaim10@gmail.com

\begin{abstract}
Abstrak. Kemiri (Aleurites moluccana) merupakan tanaman dengan berbagai macam manfaat, Saat ini kemiri sebagaian besar digunakan sebagai rempah-rempah, kulit kemiri juga memiliki nilai kalor yang cukup tinggi sehingga dapat digunakan sebagai bahan bakar. Kemiri memiliki kulit kemiri yang merupakan limbah organik. Kulit kemiri memiliki tekstur keras dan kandungan karbon yang tinggi. Sebagian besar kulit kemiri digunakan sebagai bahan bakar dan hanya sebagian kecil yang digunakan sebagai bahan baku pembuatan karbon. Kulit kemiri memiliki sifat fisik dan kimia yang baik sebagai bahan baku karbon. Karbon aktif merupakan salah satu fasa karbon yang dapat digunakan untuk berbagai aplikasi. Dalam makalah ini, kami melaporkan sintesis dan karakterisasi karbon dari kulit kemiri untuk mendapatkan karbon berkualitas tinggi dengan mengontrol suhu karbonisasi. Dalam produksi karbon, kami menggunakan variasi suhu karbonisasi sebesar 300, 400, 500, 600 dan $700{ }^{\circ} \mathrm{C}$. Analisis proksimat dilakukan untuk mengetahui kadar air, kadar abu, kadar zat terbang dan kadar karbon terikat. Analisis pengaruh suhu karbonisasi terhadap kualitas karbon dari kulit kemiri menghasilkan karbon tertinggi pada sampel dengan suhu $700{ }^{\circ} \mathrm{C}$, menghasilkan karbon dengan kadar air 5,32\%, kadar abu $9,40 \%$, kadar zat terbang $12,76 \%$, dan kadar karbon terikat $72,52 \%$.
\end{abstract}

Kata kunci: kulit kemiri, karbonisasi, limbah organik, analisis proksimat

\begin{abstract}
Candlenut (Aleurites moluccana) is a plant with various benefits. Currently, candlenut is mostly used as a spice, candlenut shells also has a high calorific value so that it can be used as fuel. Candlenut has shells which is an organic waste. Candlenut shells have a hard texture and high carbon content. Most of the candlenut shell is used as fuel and only a small part is used as raw material for carbon production. Candlenut shell have good physical and chemical properties as carbon raw materials. Activated carbon is one of the carbon phases that can be used for various applications. In this paper, we report on the synthesis and characterization of carbon from candlenut shells to obtain high-quality carbon by controlling the carbonization temperature. In carbon production, we use variations in carbonization temperatures of 300, 400, 500, 600 and $700{ }^{\circ} \mathrm{C}$. Proximate analysis was carried out to determine the moisture content, ash content, volatile matter content and bound carbon content. Analysis of the effect of carbonization temperature on the quality of carbon from candlenut shells resulted in the highest carbon in the sample with a temperature of $700{ }^{\circ} \mathrm{C}$, producing carbon with $5.32 \%$ moisture content, $9.40 \%$ ash content, $12.76 \%$ volatile matter content, and fix carbon content $72,52 \%$.
\end{abstract}

Keywords: candlenut shell, carbonization, organic waste, proximate analysis 


\section{Pendahuluan}

Kemiri (Aleurites moluccana) merupakan tanaman dengan berbagai macam manfaat. Saat ini kemiri sebagaian besar digunakan sebagai rempah-rempah, akan tetapi diketahui bahwa hampir semua bagian dari kemiri dapat dimanfaatkan. Kemiri sendiri merupakan pohon yang mudah untuk ditanam. Selain itu pohon kemiri sangat mudah tumbuh, tidak memerlukan persayaratan yang banyak, dan kulit kemiri juga memiliki nilai kalor yang cukup tinggi sehingga dapat digunakan sebagai bahan bakar [1]. Namun demikian, dengan begitu banyaknya manfaat, kemiri juga menghasilkan limbah yaitu kulit kemiri. Kulit tersebut bisa menumpuk dalam jumlah besar jika dalam musim panen. Padahal, kulit kemiri tersebut memiliki kadar karbon yang sangat besar, dan dapat dimanfaatkan sebagai adsorben atau pembuatan arang bakar [2]. Dengan memperhatikan faktor lingkungan tersebut, maka kulit kemiri dapat dimanfaatkan sebagai bahan baku pembuatan karbon. Pemanfaatan limbah kulit kemiri ini dimaksudkan selain untuk menanggulangi penumpukan limbah kulit kemiri juga diharapkan dapat menghasilkan produk yang aman dan ramah lingkungan [3][4].

Karbon dapat didefinisikan sebagai amorf yang memiliki porositas dan luas permukaan yang tinggi [5], karena struktur berpori ini, karbon aktif banyak digunakan dalam berbagai aplikasi, seperti adsorben zat warna [6], adsorben logam berat dan gas [7], katalis, elektroda (baterai dan superkapasitor) [8]. Karbon dapat disintesis dari biomassa yang tersusun dari lignoselulose. Karbon dari bahan biomassa seperti tempurung kelapa, sekam padi, tongkol jagung, eceng gondok dan bambu menjadi salah satu bahan baku yang banyak diteliti akhir-akhir ini. Beberapa laporan yang dipublikasikan menunjukkan bahwa semua bahan biomassa memiliki potensi yang baik untuk dikembangkan sebagai sumber karbon yang dapat digunakan pada berbagai aplikasi [9].

Kulit kemiri merupakan salah satu bahan biomassa yang dapat digunakan untuk pembuatan karbon. Bahan baku yang dapat digunakan untuk pengolahan karbon, persyaratannya adalah mengandung unsur karbon tinggi, baik organik maupun anorganik dan memiliki banyak pori-pori. Pada penelitian ini akan disintesis karbon dari kulit kemiri, dengan memperhatikan komponen kimianya seperti hemiselulosa 49,22 \% dan lignin 54,46\%. Lignin merupakan senyawa dengan kandungan karbon tinggi sehingga dapat digunakan sebagai bahan karbon yang menghasilkan kadar karbon terikat yang tinggi [4].

Berdasarkan penjelasan materi diatas maka dilakukan penelitian tentang sintesis karbon kulit kemiri dengan variasi suhu karbonisasi untuk mengetahui kandungan karbon. Kemudian dilakukan analisis proksimat untuk mengetahui kadar air, kadar abu, kadar zat terbang, dan karbon terikat

\section{Metode Penelitian}

Bahan yang digunakan pada penelitian ini yaitu kulit kemiri, aquades, sedangkan alat yang gunakan adalah oven, furnace, ball milling dan ayakan mesh 200. Produksi karbon dari kulit kemiri dilakukan melalui dua tahap yaitu persiapan kulit kemiri dan proses karbonisasi. Persiapan dimulai dengan memotong kulit kemiri menjadi potongan-potongan kecil berukuran 1-2 cm, kemudian dibersihkan dengan aquades untuk menghilangkan debu dan kotoran selanjutnya direndam dalam air panas. Kulit kemiri yang bersih dan berukuran kecil dijemur dibawah sinar matahari selama 6 jam, setelah itu dikeringkan dalam oven selama 24 jam pada suhu $110{ }^{\circ} \mathrm{C}$. 
Kulit kemiri kemudian dikarbonisasi dalam furnace selama 1 jam dengan variasi suhu 300, 400, 500, 600 dan $700{ }^{\circ} \mathrm{C}$, kemudian karbon tersebut dihaluskan dengan ball milling. Setelah penggilingan, semua sampel disaring dengan ayakan 200 mesh untuk mendapatkan ukuran butir yang sama dan hasil akhir berupa serbuk karbon seperti terlihat pada Gambar 1.

Seluruh sampel dikarakterisasi menggunakan analisis proksimat untuk mengetahui kadar air, kadar abu, kadar zat terbang, dan kadar karbon terikat. Kualitas karbon aktif tergantung pada jenis bahan baku dan teknologi pengolahan yang digunakan. Baku mutu karbon aktif telah diatur dalam Standar Nasional Indonesia (SNI 063730-1995) [10]

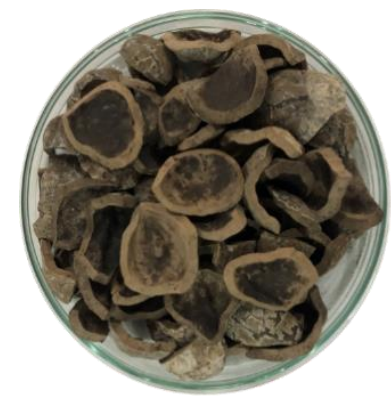

(a)

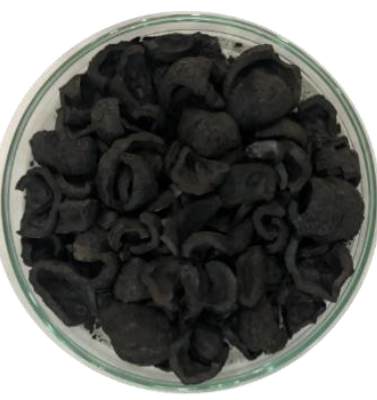

(b)

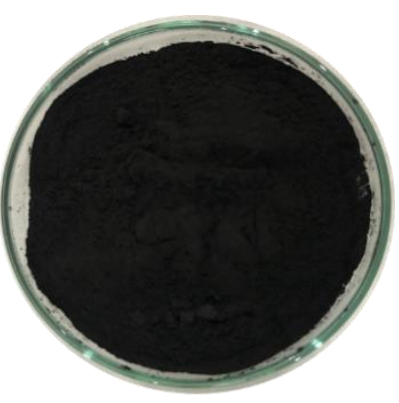

(c)

Gambar 1. Foto (a) Kulit Kemiri, (b) Karbon Kulit Kemiri, dan (c) Karbon kemiri mesh 200

\section{Hasil dan Pembahasan}

Proses karbonisasi adalah proses meningkatkan kandungan karbon dari bahan dasar pada suhu dibawah $800{ }^{\circ} \mathrm{C}$ dalam tekanan atmosfer inert. Pada proses karbonisasi, sebagian besar unsur non karbon seperti oksigen, hidrogen, dan nitrogen akan hilang sebagai jenis gas yang diuapkan oleh proses karbonisasi terhadap bahan. Proses karbonisasi ini bertujuan untuk menguraikan senyawa-senyawa hidrokarbon seperti selulosa, hemiselulosa dan lignin menjadi karbon murni dan menghasilkan butiran yang memiliki daya serap tinggi [11]. Untuk mengetahui pengaruh variasi suhu karbonisasi terhadap kualitas karbon maka dilakukan karakterisasi menggunakan analisis proksimat. Hasil karakterisasi untuk mengetahui kadar air, kadar abu, kadar zat terbang, dan karbon terikat dapat dilihat pada Tabel 1.

Tabel 1. Hasil karakterisasi proksimat tentang karbon dari kulit kemiri

\begin{tabular}{|c|c|c|c|c|c|c|}
\hline \multirow{2}{*}{$\begin{array}{c}\text { Karakteristik } \\
(\%)\end{array}$} & \multicolumn{5}{|c|}{ Suhu Karbonasi $\left({ }^{\circ} \mathrm{C}\right)$} & \multirow{2}{*}{$\begin{array}{c}\text { SNI } \\
(06-3730-1995) \\
\end{array}$} \\
\hline & 300 & 400 & 500 & 600 & 700 & \\
\hline Kadar Air & 5,20 & 6,90 & 6,10 & 6,16 & 5,32 & $4,5-15$ \\
\hline Kadar Abu & 10,23 & 6.06 & 5,28 & 8,64 & 9.40 & $\leq 10$ \\
\hline Kadar Zat terbang & 52,53 & 33,16 & 22,62 & 17,12 & 12,76 & $\leq 15$ \\
\hline Karbon Terikat & 32.04 & 53,88 & 66,00 & 68,08 & 72,52 & $\geq 65$ \\
\hline
\end{tabular}

Kadar air didefinisikan sebagai banyaknya air yang ada dalam suatu bahan, penentuan kadar air karbon bertujuan untuk mengetahui sifat higroskopis karbon kulit kemiri [12]. Berdasarkan Tabel 1 terlihat bahwa kadar air yang diperoleh dari penelitian ini berkisar antara 5,2-6,9\% dan hasil tersebut memenuhi standar (SNI 
06-3730-1995) yaitu kadar air maksimum 15\%. Data pada Tabel 1 menunjukkan bahwa kadar air relatif sama, dimana nilai kadar air pada sampel kulit kemiri karbonisasi $400{ }^{\circ} \mathrm{C}$ paling tinggi yaitu 6,90\%. Penurunan kadar air ini berkaitan dengan suhu karbonisasi [13]. Dalam penelitian Gusti Gilang dkk menyatakan karbon kulit kemiri dengan variasi konsentrasi aktivator kimia menunjukkan nilai kadar air 2,30\% dan 5,75\%, dapat disimpulkan bahwa semakin besar konsentrasi yang diberikan, maka semakin tinggi kadar air karbon kulit kemiri yang dihasilkan [12].

Kadar air yang tinggi akan mempengaruhi sifat higroskopis dari karbon kulit kemiri, jumlah air diudara, lamanya proses pendinginan, penggilingan, dan pengayakan. Semakin rendah kadar air menunjukkan semakin sedikit air yang tersisa dan menutupi pori-pori karbon. Semakin besar pori-pori maka semakin tinggi luas permukaan karbon [14].

Salah satu sifat kualitas karbon adalah rendahnya kadar abu, abu merupakan oksida logam dalam karbon yang terdiri dari mineral-mineral yang tidak dapat diuapkan dalam proses karbonisasi. Kadar abu diasumsikan sebagai sisa mineral yang tertinggal pada saat karbonisasi, karena bahan alam sebagai bahan dasar pembuatan karbon tidak hanya mengandung senyawa karbon, tetapi juga mengandung beberapa mineral, senyawa tersebut ada yang hilang pada saat karbonisasi, ada yang diperkirakan tertinggal dalam karbon [11]. Kadar abu sangat mempengaruhi kualitas karbon yang dihasilkan. Adanya abu yang berlebihan dapat menyebabkan tersumbatnya pori-pori pada karbon sehingga luas permukaan karbon berkurang [12].

Berdasarkan Tabel 1 terlihat bahwa kadar abu yang diperoleh dari penelitian ini berkisar antara 5,2-10\% dan hasil tersebut memenuhi standar (SNI 06-3730-1995) yaitu kadar abu maksimum 10\%. Kurva kadar abu dapat dilihat pada Gambar 2 dan data pada Tabel 1 menunjukkan adanya variasi kadar abu, peningkatan kadar abu terjadi dari suhu karbonisasi $500-700{ }^{\circ} \mathrm{C}$ dimana nilai kadar abu untuk sampel karbon dari kulit kemiri $300{ }^{\circ} \mathrm{C}$ lebih tinggi dari pada sampel lainnya, hal ini diprediksi karena pada suhu $300{ }^{\circ} \mathrm{C}$ belum terjadi karbonisasi secara sempurna, maka dari itu terjadi peningkatan kadar abu. Kadar abu karbon yang tinggi disebabkan oleh proses oksidasi dan adanya kontak dengan udara luar pada saat proses pembakaran lebih lanjut dimana karbon yang terbentuk sebagian berubah menjadi abu [15].

Harits Fadhillah dkk menyatakan nilai kadar abu karbon kulit kemiri dengan variasi penambahan $\mathrm{KMnO}_{4}$ menghasilkan kadar abu pada rentang 7-8,5 \% semakin banyak penambahan $\mathrm{KMnO}_{4}$ semakin banyak kadar abu yang dihasilkan [16]. Besarnya kadar abu dapat mempengaruhi penyerapan karbon terhadap gas dan larutan, karena kandungan mineral dalam abu seperti kalsium, kalium, magnesium, dan natrium akan tersebar didalam kisi karbon, adanya abu yang berlebihan dapat menyumbat pori-pori sehingga luas permukaan karbon berkurang [17].

Penentuan kadar zat terbang bertujuan untuk mengetahui kandungan senyawa yang dapat menguap pada suhu $950{ }^{\circ} \mathrm{C}$. Pada pemanasan di atas $900{ }^{\circ} \mathrm{C}$ nitrogen dan belerang akan menguap, dan komponen ini disebut volatile matter [14]. Kadar zat terbang yang dihasilkan dari penelitian ini berkisar antara 12,78\% - 53,53\%. 


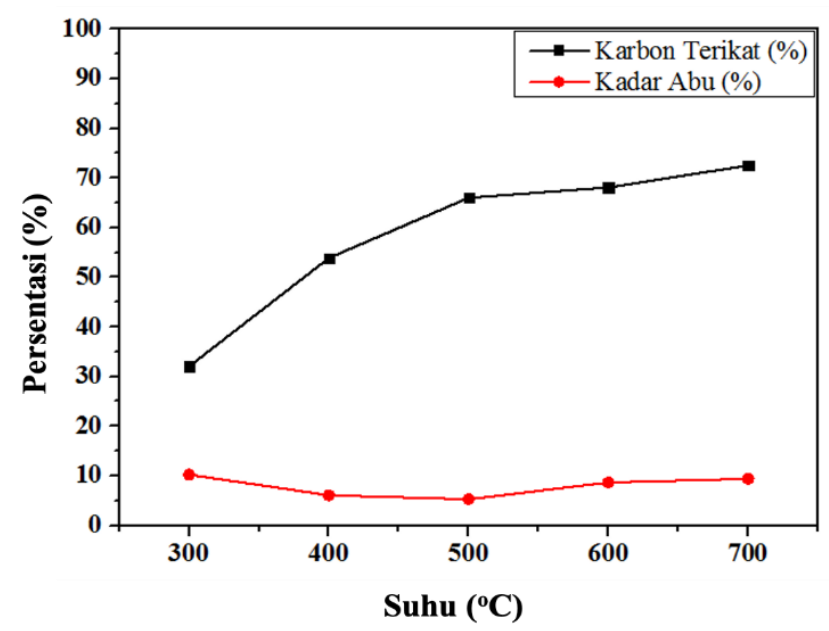

Gambar 2. Kurva kadar abu dan karbon terikat

Hasil analisis menunjukkan bahwa semakin tinggi suhu karbonisasi kadar zat terbang yang diperoleh semakin kecil. Tabel 1 menunjukkan bahwa kandungan zat terbang tertinggi dihasilkan oleh karbon pada suhu $300{ }^{\circ} \mathrm{C}$ sebesar 52,3\%, sedangkan kandungan zat terbang terendah dihasilkan oleh karbon pada suhu $700{ }^{\circ} \mathrm{C}$ sebesar $12,76 \%$, hal ini terjadi karena suhu karbonisasi yang tinggi akan menyebabkan kadar abu berupa oksida logam dalam karbon yang terdiri dari mineral tidak dapat menguap lebih tinggi, sedangkan mineral yang mudah menguap pada suhu lebih tinggi akan menyebabkan evaporasi unsur yang mudah menguap semakin tinggi pula, akibatnya kandungan zat terbang pada karbon berkurang [11].

Kadar zat terbang pada suhu karbonisasi $300-400{ }^{\circ} \mathrm{C}$ tidak memenuhi standar (SNI06-3730-1995) yaitu maksimal 25\%, sedangkan kadar zat terbang pada suhu karbonisasi 500-700 ${ }^{\circ} \mathrm{C}$ memenuhi standar (SNI-06-3730-1995). Tingginya kadar zat terbang menunjukkan bahwa masih terdapat senyawa non karbon yang menempel pada permukaan karbon terutama atom $\mathrm{H}$ dan $\mathrm{O}$ yang terikat kuat pada atom $\mathrm{C}$ pada permukaan karbon berupa $\mathrm{CO}_{2}, \mathrm{CO}, \mathrm{CH}_{4}$, dan $\mathrm{H}_{2}$ [14].

Kandungan karbon terikat adalah jumlah karbon murni yang terdapat dalam sampel. Penentuan kadar karbon bertujuan untuk mengetahui nilai atau jumlah karbon murni yang terkandung dalam karbon aktif [15]. Kurva kandungan karbon terikat dan kadar abu dapat dilihat pada Gambar 2. Karbon terikat yang dihasilkan dari penelitian ini berkisar antara 32,04\% - 72,52\%. Karbon terikat tertinggi dihasilkan oleh sampel pada suhu karbonisasi $700{ }^{\circ} \mathrm{C}$ sebesar $72,52 \%$ dan karbon terikat terendah yang dihasilkan oleh $300{ }^{\circ} \mathrm{C}$ adalah 32,04\%. Gusti Gilang, dkk menyatakan karbon terikat pada karbonisasi kulit kemiri sebesar 23,30\%. semakin tinggi konsentrasi $\mathrm{NaOH}$ maka semakin tinggi kadar karbon terikat yang terkandung didalam karbon aktif [12]. Selain itu Rina Novia dkk menyatakan bahwa karbon dari kulit kelapa sawit yang diaktivasi $\mathrm{H}_{3} \mathrm{PO}_{4}$ dengan suhu $750{ }^{\circ} \mathrm{C}$ memiliki karbon terikat pada kisaran 66-77\%, konsentrasi $\mathrm{H}_{3} \mathrm{PO}_{4}$ mempengaruhi kadar karbon yang dihasilkan [18].

Hasil analisis menunjukkan bahwa suhu karbonisasi berpengaruh terhadap kadar karbon terikat dari karbon kulit kemiri. Pada Gambar 2 dan Tabel 1 menunjukkan bahwa semakin tinggi suhu karbonisasi maka semakin tinggi kadar karbon terikat 
yang terdapat pada kulit kemiri. Karbon terikat dalam penelitian ini rentang suhu karbonisasi 500-700 ${ }^{\circ} \mathrm{C}$ telah memenuhi kualitas persyaratan karbon terikat (SNI06-3730- 1995). Sedangkan pada suhu karbonisasi 300-400 ${ }^{\circ} \mathrm{C}$ tidak memenuhi kualitas karbon terikat pada standar (SNI-06-3730-1995) yaitu minimal 65\%. Hal ini disebabkan kandungan abu dan kadar zat terbang yang tinggi sehingga karbon terikat yang dihasilkan kecil. Semakin tinggi kadar abu dan kadar zat terbang, semakin rendah karbon terikat dari kulit kemiri. Hal ini disebabkan proses karbonisasi yang tidak sempurna, karbonisasi yang sempurna dapat menghasilkan karbon terikat yang lebih tinggi [2].

\section{Kesimpulan}

Telah dilakukan sintesis karbon dari limbah kulit kemiri dengan beberapa variasi suhu karbonisasi dan telah dilakukan analisis proksimat untuk mengetahui kadar air, kadar abu, kadar zat terbang dan kadar karbon terikat. Hasil analisis proksimat dari karbn kulit kemiri diketahui bahwa nilai karbon terikat akan meningkat seiring dengan naiknya suhu karbonisasi. Hasil penelitian ini menunjukan bahwa karbonisasi pada suhu 700 oC menghasilkan kualitas karbon terbaik dengan kadar air 5,32\%, kadar abu 9,40\%, kadar zat terbang $12,76 \%$, dan kadar karbon terikat $72,52 \%$. Nilai analisis proksimat tersebut telah memenuhi standar SNI untuk karbon aktif menurut (SNI-06-3730-1995).

\section{Ucapan Terima Kasih}

Penulis mengucapkan terima kasih kepada Kemenristek-Dikti Indonesia atas dukungan finansial Pendanaan Hibah Penelitian Dasar Kontrak No: 1207/UN6.3.1/PT.00/2021

\section{Daftar Pustaka}

1. S. Nur and Halimah, "Pembuatan Dan Karakterisasi Serta Uji Adsorpsi Karbon Aktif Tempurung Kemiri (Aleurites Moluccana ) Terhadap Metilen Biru," pp. 3345-3356, 2016.

2. J. Latupeirissa, M. F. J. D. P. Tanasale, and K. Dade, "Carbon Characterization from Candlenut Shells (Aleurites Moluccana (L) Willd) with XRD," Indones. J. Chem. Res., vol. 3, no. 2, pp. 324-328, 2016.

3. T. H. Jatmiko, "Pemanfaatan Karbon Aktif dari Limbah Tempurung Kemiri untuk Adsorpsi Limbah Merkuri-Hg (II)," Pros. Semin. Nas. Peran Teknol. di Era Glob., no. November 2013, pp. 121-125, 2013.

4. S. A. Aktif, T. Kemiri, and M. Lempang, "Sifat-Sifat Arang Tempurung Kemiri dan Aplikasinya Sebagai Komponene Media Tumbuh Pada Tanaman Melina ( Gmelina arborea Roxb .),” 2009.

5. N. R. Villarante, R. A. E. Davila, and D. P. Sumalapao, "Removal of lead $(\alpha)$ by lumbang, aleurites moluccana activated carbon carboxymethylcellulose composite crosslinked with epichlorohydrin," Orient. J. Chem., vol. 34, no. 2, pp. 693-703, 2018, doi: 10.13005/ojc/340211.

6. K. M. Doke, M. Yusufi, R. D. Joseph, and E. M. Khan, "Comparative Adsorption of Crystal Violet and Congo Red onto ZnCl2 Activated Carbon," 
J. Dispers. Sci. Technol., vol. 37, no. 11, pp. 1671-1681, 2016, doi: 10.1080/01932691.2015.1124342.

7. S. S. A. Syed-Hassan and M. S. M. Zaini, "Optimization of the preparation of activated carbon from palm kernel shell for methane adsorption using Taguchi orthogonal array design," Korean J. Chem. Eng., vol. 33, no. 8, pp. 2502-2512, 2016, doi: 10.1007/s11814-016-0072-z.

8. A. A. Arie, H. Kristianto, I. Suharto, M. Halim, and J. K. Lee, "Preparation of orange peel based activated carbons as cathodes in lithium ion capacitors," Adv. Mater. Res., vol. 896, pp. 95-99, 2014, doi: 10.4028/www.scientific.net/AMR.896.95.

9. D. C. S. Azevedo, J. C. S. Araújo, M. Bastos-Neto, A. E. B. Torres, E. F. Jaguaribe, and C. L. Cavalcante, "Microporous activated carbon prepared from coconut shells using chemical activation with zinc chloride," Microporous Mesoporous Mater., vol. 100, no. 1-3, pp. 361-364, 2007, doi: 10.1016/j.micromeso.2006.11.024.

10. Badan Pusat Statistik (BPS) Badan Pusat Statistik Nasional. 2014.

11. S. Maulina and M. Iriansyah, "Characteristics of activated carbon resulted from pyrolysis of the oil palm fronds powder," IOP Conf. Ser. Mater. Sci. Eng., vol. 309, no. 1, 2018, doi: 10.1088/1757-899X/309/1/012072.

12. G. G. R. Maulana, L. Agustina, and S. Susi, "Proses Aktivasi Arang Aktif Dari Kulit Kemiri (Aleurites Moluccana) Dengan Variasi Jenis Dan Konsentrasi Aktivator Kimia," Ziraa'ah Maj. Ilm. Pertan., vol. 42, no. 3, pp. 247-256, 2017, doi: 10.31602/zmip.v42i3.897.

13. L. G. Egea, R. Jiménez-Ramos, I. Hernández, and F. G. Brun, "Effect of In Situ short-term temperature increase on carbon metabolism and dissolved organic carbon (DOC) fluxes in a community dominated by the seagrass Cymodocea nodosa," PLoS One, vol. 14, no. 1, pp. 1-20, 2019, doi: 10.1371/journal.pone.0210386.

14. Verayana, M. Paputungan, and $\mathrm{H}$. Iyabu, "Pengaruh Aktivator $\mathrm{HCl}$ dan $\mathrm{H}$ 3PO4 terhadap Karakteristik (Morfologi Pori) Arang Aktif Tempurung Kelapa serta Uji Adsorpsi pada Logam Timbal (Pb), J. Entropi, vol. 13, no. 1, pp. 6775, 2018.

15. O. Nurhilal et al., "Synthesis of High Quality Porous Carbon from Water Hyacinth," Key Eng. Mater., no. 860, pp. 173 - 177, 2020, doi: 10.1039/c5ra25098f.

16. T. E. P. S. R. Harits Fadhillah Immaduddin, Shafwan Amrullah, Nurkholis, "Pengolahan Limbah Tempurung Kemiri Sebagai Adsorben Senyawa Etilen Dengan Penambahan Kalium Permanganat ( KMnO 4 )," vol. 3, no. 01, pp. 1319, 2021.

17. M. Sánchez-Cantú, V. J. Janeiro-Coronel, J. A. Galicia-Aguilar, and J. D. Santamaría-Juárez, "Effect of the activation temperature over activated carbon production from castor cake and its evaluation as dye adsorbent," Int. J. Environ. Sci. Technol., vol. 15, no. 7, pp. 1521-1530, 2018, doi: 10.1007/s13762-017-1532-7.

18. R. Yanti Novia, E. Hambali, G. Pari, and A. Suryani, "Karakteristik Arang Aktif Tandan Kosong Kelapa Sawit Yang Dimpregnasi Logam Nikel Sebagai Katalis," J. Penelit. Has. Hutan, vol. 38, no. 3, pp. 129-138, 2020, doi: 10.20886/jphh.2020.38.3.129-138. 